\title{
A CLNICAL AND HAEMATOLOGICAL PROFILE OF HIV POSITIVE PATIENTS AT A TERTIARY CARE HOSPITAL WITH SPECIAL REFERENCE TO OPPORTUNISTIC INFECTIONS
}

Anil Mudda ${ }^{1}$, Satyanarayana. N², T. Anil Kumar ${ }^{3}$, Sanjeev Kumar S. Gunjigavi ${ }^{4}$, Ravi Kumar ${ }^{5}$, Sai Shruthi 6

\section{HOW TO CITE THIS ARTICLE:}

Anil Mudda ${ }^{1}$, Satyanarayana. N², T. Anil Kumar ${ }^{3}$, Sanjeev Kumar S. Gunjigavi ${ }^{4}$, Ravi Kumar ${ }^{5}$, Sai Shruthi."A Clinical and Hematological profile of HIV positive patients at A Tertiary Care Hospital with special reference to Opportunistic Infections". Journal of Evolution of Medical and Dental Sciences 2014; Vol. 3, Issue 01, January 06; Page: 20-29.

ABSTRACT: BACKGROUND: HIV/AIDS remains one of the world's most significant public health challenges, particularly in low- and middle-income countries.HIV affects the immune system. Its effects are seen in all the systems of the body. These manifestations may be due to HIV infection itself or due to opportunistic infections or malignancies. The clinical and pathologic findings in various organ systems including the pulmonary, skin, gastrointestinal, hematological and nervous systems have been well described in the young adult population. The present study was undertaken to study the presentation of HIV/AIDS infection. OBJECTIVES: 1 . To study the clinical profile of HIV positive patients.2. To study about the hematological manifestations in HIV positive patients.3. To study the pattern of opportunistic infections in HIV positive patients. DESIGN: This was a hospital based cross sectional study conductedover a period of 2 years from September 2011 to September 2013.SETTING: ESIC Medical College \& Post Graduate Institute Of Medical Science \&Research Rajajinagar, Bengaluru. METHODS: This study was conducted in Department of General medicine, ESIC-MC \& PGIMSR, Rajajinagar, Bangalore. $100 \mathrm{HIV}$ positive patients were included in the study. RESULTS: In this study, out of 100 HIV positive patients, $62 \%$ ofpatients were males and $38 \%$ females. $56 \%$ patients were in the age group of $31-40$ years. $61 \%$ of patients presented with fever as main symptom followed by weight loss as the next most common mode of presentation.38\% belonged to tuberculosis group (both pulmonary and extra pulmonary) and 68\% to the nontuberculosis group. Among the tuberculosis group, 16\% of patients had pulmonary tuberculosis (PTB). $8 \%$ of the patients had tubercular lymphadenopathy. $10 \%$ of patients had abdominal tuberculosis and $4 \%$ had tubercular meningitis.60\% patients had absolute lymphocyte count (ALC) of $<1000 / \mathrm{mm}^{3}$ and $40 \%$ patients had $>1000 / \mathrm{mm}^{3}$. 46\% patients had CD4 count of less than $200 / \mathrm{mm}^{3}$ and $54 \%$ patients had $>200 / \mathrm{mm}^{3}$.CD4 count is significantly correlated with ALC with a P value $=0.023^{*}$.CONCLUSION: Majority of HIV positive patients presented with increased incidence of fever, weight loss, chronic diarrhea, cough and oral candidiasis. Most of the adults with HIV presented with AIDS defining illnesses and most of them presented with multiple concurrent opportunistic infections. Categorically most of them presented with WHO stage 3 or stage 4 illnesses. KEY WORDS: HIV, AIDS, ALC, CD4 Count, Pulmonary Tuberculosis, Opportunistic infections.

INTRODUCTION: AIDS was first clinically observed in 1981 in the United States ${ }^{1}$. The initial cases were a cluster of injection drug users and gay men with no known cause of impaired immunity who showed symptoms of Pneumocystis carinii pneumonia (PCP), a rare opportunistic infection that was known to occur in people with much compromised immune systems ${ }^{2}$. Soon thereafter, additional 


\section{ORIGINAL ARTICLE}

homosexual men developed a rare skin cancer called Kaposi's sarcoma (KS) 3,4. Many more cases of PCP and KS emerged, alerting U.S. Centers for Disease Control and Prevention (CDC) and a CDC task force was formed to monitor the outbreak ${ }^{5}$.

HIV/AIDS remains one of the world's most significant public health challenges, particularly in low- and middle-income countries. As a result of recent advances in access to antiretroviral therapy (ART), HIV-positive people now live longer and healthier lives. In addition, it has been confirmed that ART prevents onward transmission of HIV.

At the end of 2012, close to 10 million people were receiving ART in low- and middle-income countries. However, almost 19 million other people who are eligible for ART under new 2013 guidelines do not have access to antiretroviral drugs.

The spectrum of HIV infection includes asymptomatic cases to AIDS at other extreme. The diagnosis rests on clinical manifestations and laboratory markers. In India the socioeconomic and cultural environment is important in disease transmission and prevalence, as also the clinical spectrum is very different from western society.

The purpose of this study was to know the different patterns of clinical presentation of HIV infection in this region.

\section{OBJECTIVES:}

1. To study the clinical profile of HIV positive patients.

2. To study about the hematological manifestations in HIV positive patient.

3. To study the pattern of opportunistic infections.

Design: This was a hospital based cross sectional study conducted over a period of 2 years from September 2011 to September 2013.

Setting: ESIC MEDICAL COLLEGE \& POST GRADUATE INSTITUTE OF MEDICAL SCIENCE \&RESEARCH RAJAJINAGAR, BENGALURU. Patients were subjected to a detailed history and complete physical examination. Data was collected in a predesigned Performa. Patients taken in to study were tested for HIV, absolute lymphocyte count and CD4 count.

Method of collection of data: This study was conducted in Department of General medicine, ESICMC \& PGIMSR, Rajajinagar, and Bangalore. 100 HIV positive patients were included in the study.

Informed consent was taken prior to inclusion in the study.

Various samples e.g. sputum, oral swab, blood, stool, urine, cerebrospinal fluid (CSF) and lymph node aspirate were collected as per symptoms and clinical presentations.

All the specimens were collected under universal aseptic precautions in suitable sterile containers.

\section{Inclusion criteria:}

1. HIV positive patients as per NACO guidelines.

2. Patients aged above 18 years.

3. Patients who were willing to give written signed consent.

\section{Exclusion criteria:}

1. Below 18 years of age.

Statistical Methods: Descriptive and inferential statistical analysis has been carried out in the present study. Results on continuous measurements are presented on Mean SD (Min-Max) and results on categorical measurements are presented in Number (\%). 


\section{ORIGINAL ARTICLE}

Analysis of variance (ANOVA) has been used to find the significance of study parameters between three or more groups of patients, Student $t$ test (two tailed, independent)has been used to find the significance of study parameters on continuous scale between two groups Inter group analysis) on metric parameters.

Leven1s test for homogeneity of variance has been performed to assess the homogeneity of variance.

Chi-square/ Fisher Exact test has been used to find the significance of study parameters on categorical scale between two or more groups.

Statistical software: The Statistical software namely SAS 9.2, SPSS 15.0, Stata 10.1, MedCalc 9.0.1, Systat 12.0 and R environment ver.2.11.1 were used for the analysis of the data and Microsoft word and Excel have been used to generate graphs, tables etc.

RESULTS: In this study, out of 100 people, $62 \%$ of patients were males and $38 \%$ females. $56 \%$ patients were in the age group of 31-40 years (Table 1, Fig 1). 61\%of patients presented with fever as main symptom followed by weight loss as the next most common mode of presentation.

$38 \%$ belonged to tuberculosis group (both pulmonary and extra pulmonary) and 62\% to the non-tuberculosis group.16\% of patients had pulmonary tuberculosis (PTB). Presence of PTB was significantly associated with Lower CD4 count with $\mathrm{P}<0.001^{* *} .8 \%$ of the patients had tubercular lymphadenopathy. $10 \%$ of patients had abdominal tuberculosis. $4 \%$ of our patients had tubercular meningitis.

$14 \%$ patients had severe anemia.59\% patients had high ESR (>60).60\% patients had ALC $<1000 / \mathrm{mm}^{3}$ and $40 \%$ patients had $>1000 / \mathrm{mm}^{3}$.Absolute Lymphocyte Counts of $609.64 \pm 277.03 / \mu \mathrm{l}$ and $702.38 \pm 311.83$ cells $/ \mu$ l showed observations similar to CD 4 counts of $<100$ cells $/ \mu \mathrm{l}$ and $<200$ cells/ $\mu$ l respectively. The $\mathrm{P}$ value was highly significant. $46 \%$ patients had CD4 count of less than $200 / \mathrm{mm}^{3}$ and $54 \%$ patients had $>200 / \mathrm{cmm}$.CD4 count was significantly associated with ALC with $\mathrm{P}=0.023^{*}$.

DISCUSSION: In this study, out of 100 people, 62\% of patients were males and 38\% females. $56 \%$ patients were in the age group of 31-40years.Study done by Kothari K etal6 in 2001 showed that $90 \%$ of the cases were in the age group of 20 to 40 years and male population constituted $83.33 \%$.

Ghate M.V et $\mathrm{al}^{7}$ in their study on changing trends in clinical presentation of HIV infected persons in Pune, found that $88.1 \%$ of the cases were in the age group between 21 years and 40 years and it was the male population that was more affected as compared to the females.

In a study done by Mandal A.K et al ${ }^{8}, 81.16 \%$ of cases were in the age group of 20 to 40 years. $61 \%$ of patients presented with fever as main symptom followed by weight loss as the next most common mode of presentation. This finding is comparable with other studies done by Colebunders Ret $\mathrm{al}^{9}$, which showed fever and weight loss in $21.83 \%$ and $29.31 \%$, Lakshmi V. et al ${ }^{10}$ in $61 \%$ and $45 \%$, Kothari $\mathrm{K}$ et al in $96 \%$ and $66 \%$ of cases.

$38 \%$ belonged to tuberculosis group, both pulmonary (16\%) and extra pulmonary (18\%) and $62 \%$ to the non-tuberculosis group. Chacko Set al ${ }^{11}$ reported incidence of pulmonary tuberculosis of $30 \%$ and extra pulmonary tuberculosis constituting $22 \%$. 


\section{ORIGINAL ARTICLE}

$60 \%$ patients had ALC $<1000 / \mathrm{mm}^{3}$ and $40 \%$ patients had $>1000 / \mathrm{mm}^{3}$ Absolute Lymphocyte Counts of $609.64 \pm 277.03 / \mu \mathrm{l}$ and $702.38 \pm 311.83$ cells/ $\mu \mathrm{l}$ showed observations similar to CD 4 counts of $<100$ cells $/ \mu \mathrm{l}$ and $<200$ cells $/ \mu \mathrm{l}$ respectively. The P value was highly significant.

$46 \%$ patients had CD4 count of less than $200 / \mathrm{mm}^{3}$ and $54 \%$ patients had $>200 / \mathrm{cmm}$.CD 4 count is significantly associated with ALC with $\mathrm{P}=0.023^{*}$

A study conducted by John Hopkins University showed a significant correlation between TLC of less than 1200 cells/ $\mu$ l to CD 4 count of less than 200 cells $/ \mu l^{12}$.

\section{REFERENCES:}

1. Dolin, Gerald L. Mandell, John E. Bennett, Raphael (2010). Mandell, Douglas, and Bennett's principles and practice of infectious diseases (7th ed.). Philadelphia, PA: Churchill Livingstone/Elsevier. pp. Chapter 169.ISBN 978-0-443-06839-3.

2. Gottlieb MS (2006). "Pneumocystis pneumonia-Los Angeles.1981".Am J Public Health 96 (6): 980-1; discussion 982-3. doi:10.2105/AJPH.96.6.980. PMC 1470612.PMID 16714472.Archived from the original on April 22, 2009.Retrieved March 31, 2009.

3. Friedman-Kien AE (October 1981). "Disseminated Kaposi's sarcoma syndrome in young homosexual men". J. Am. Acad. Dermatol. 5 (4): 468-71. doi: 10.1016/S0190-9622(81)800102. PMID 7287964.

4. Hymes KB, Cheung T, Greene JB, et al. (September 1981). "Kaposi's sarcoma in homosexual men-a report of eight cases". Lancet 2 (8247): 598-600. doi: 10.1016/S0140-6736(81)927409. PMID 6116083.

5. BBasavapathruni, A; Anderson, KS (December 2007). "Reverse transcription of the HIV-1 pandemic". The FASEB Journal 21 (14): 3795-3808. doi: 10.1096/fj.07-8697rev. PMID 17639073.

6. Kothari K., Goyal S. Study of clinical presentation, spectrum of systemic involvement and opportunistic infections in AIDS patients Journal of Association of Physicians of India. 2001; 49: 435-438.

7. Ghate M.V., Divekar A.D, Risbud AR. Changing Trends in clinical presentation in referred Human immunodeficiency virus infected persons in Pune, Indian Journal of Association of Physicians of India 2002; 50: 671- 673.

8. Mandal AK, Singh V. P., Gulati AK. Prevalence of Human Immunodeficiency virus infection in and around Varanasi, UttarPradesh.Indian Journal of Association of Physicians of India. 2000; 48 (3) 288 - 289.

9. Colebunders Robert, Mann JM, Henry Francis, KapitaBila, LebugheIzaley, Ndangikakonde et al. Evaluation of clinical case Definition of Acquired immuno deficiency syndrome in Africa. Lancet.1987; 492 - 494.

10. Lakshmi V, Teja V.D., Sudha Rani T. Human immuno deficiency virus infection in a Tertiary care Hospital - Clinical and microbiological profile. Journal of Association of Physicians of India.1998; 46; 363 - 367.

11. Chacko S, John TJ, Babu PG, Jacob M, Kaur A, Mathai D. Clinical profile of AIDS in India; a review of 61 cases. J Assoc Physicians India; 1995; 43:535-8.

12. AIDS development can be monitored and predicted John Hopkins University Bloomeberg School of Public Health 10 Sept 2003. 


\section{ORIGINAL ARTICLE}

\begin{tabular}{|c|c|c|}
\hline Age in years & No. of patients & $\mathbf{\%}$ \\
\hline $21-30$ & 26 & 26.0 \\
\hline $31-40$ & 56 & 56.0 \\
\hline $41-50$ & 14 & 14.0 \\
\hline $51-60$ & 4 & 4.0 \\
\hline Total & 100 & 100.0 \\
\hline
\end{tabular}

Table 1: Showing age distribution of patients studied

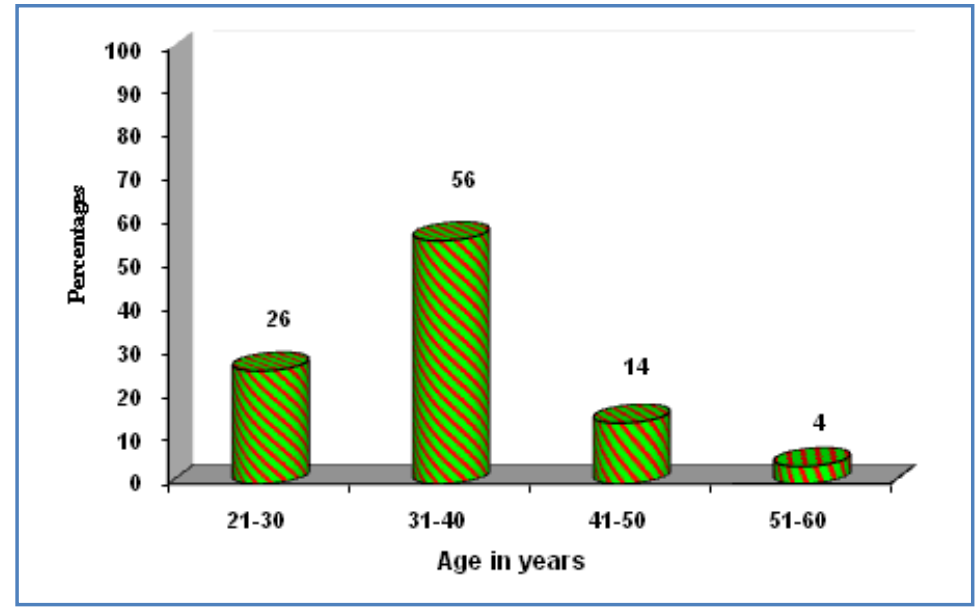

Fig. 1: Showing age distribution of patients studied

In our study majority(56\%) of patients were in the age group of 31-40years.

\begin{tabular}{|c|c|c|}
\hline Gender & No. of patients & $\mathbf{\%}$ \\
\hline Female & 38 & 38.0 \\
\hline Male & 62 & 62.0 \\
\hline Total & 100 & 100.0 \\
\hline
\end{tabular}

Table 2: Showing gender distribution of patients studied

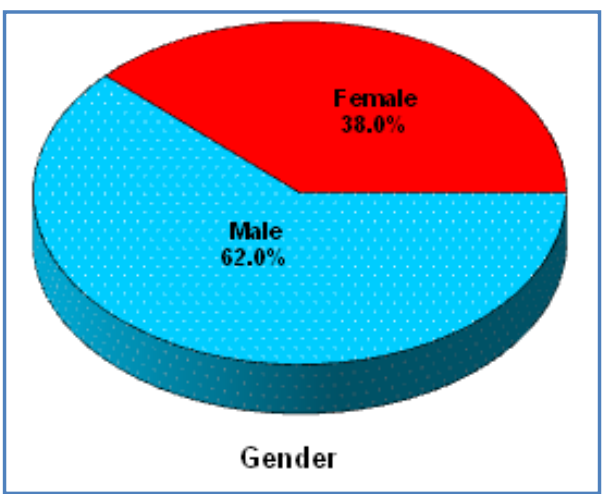

\section{Fig. 2: Showing gender distribution of patients studied}

Out of 100 patients in our study $62 \%$ were males and $38 \%$ were females. 


\section{ORIGINAL ARTICLE}

\begin{tabular}{|c|c|c|}
\hline Clinical Features & Number & Percentage \\
\hline Fever & 61 & $61 \%$ \\
\hline Cough & 38 & $38 \%$ \\
\hline Breathlessness & 32 & $32 \%$ \\
\hline Weight loss & 53 & $53 \%$ \\
\hline Diarrhoea & 38 & $38 \%$ \\
\hline
\end{tabular}

Table 3: Showing major clinical features in the study subjects.

Majority of patients presented with fever (61\%) followed by weight loss.

\begin{tabular}{|c|c|c|}
\hline Pulmonary Tuberculosis & No. of patients & $\mathbf{\%}$ \\
\hline Absent & 84 & 84.0 \\
\hline Present & 16 & 16.0 \\
\hline Total & 100 & 100.0 \\
\hline
\end{tabular}

Table 4: Showing distribution pattern of pulmonary tuberculosis

In our study $16 \%$ of patients had pulmonary tuberculosis

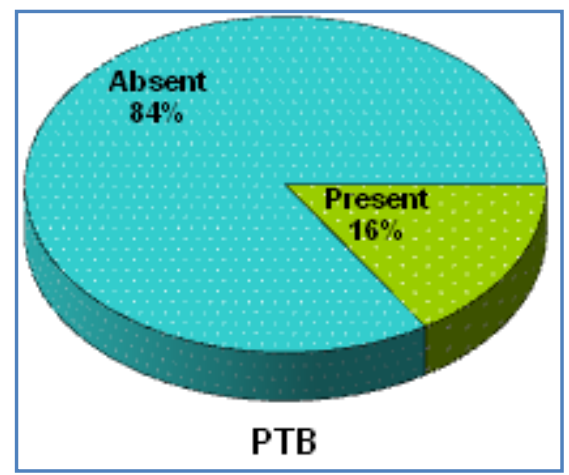

Fig. 3: Showing distribution pattern of pulmonary tuberculosis

\begin{tabular}{|c|c|c|}
\hline TB Lymphadenopathy & No. of patients & $\mathbf{\%}$ \\
\hline Absent & 92 & 92.0 \\
\hline Present & 8 & 8.0 \\
\hline Total & 100 & 100.0 \\
\hline
\end{tabular}

Table 5: Showing distribution pattern of Tubercular lymphadenopathy

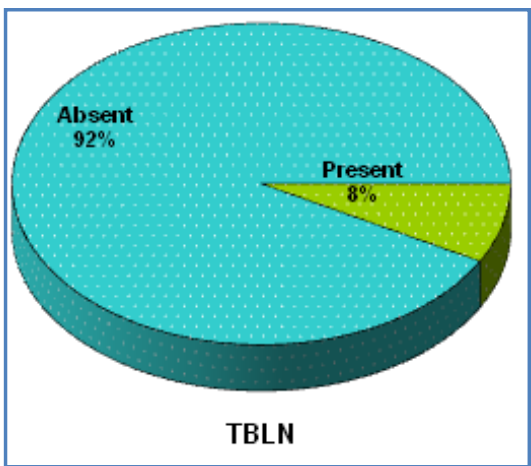

Fig. 4: Showing distribution pattern of Tubercular lymphadenopathy

In this study $8 \%$ of the patients had tubercular lymphadenopathy 


\section{ORIGINAL ARTICLE}

\begin{tabular}{|c|c|c|}
\hline Abdominal TB & No. of patients & $\mathbf{\%}$ \\
\hline Absent & 90 & 90.0 \\
\hline Present & 10 & 10.0 \\
\hline Total & 100 & 100.0 \\
\hline
\end{tabular}

Table 6: Showing distribution pattern of Abdominal Tuberculosis

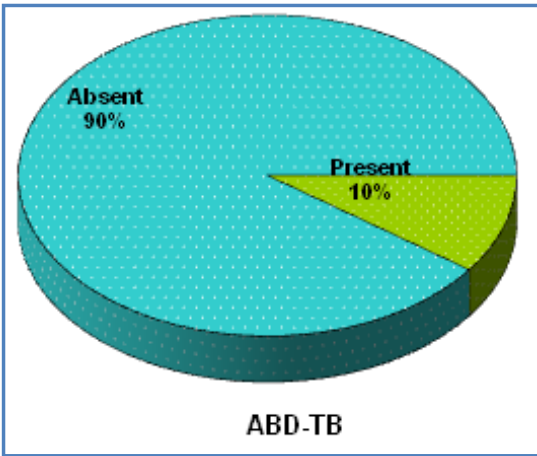

\section{Fig. 5:Showing distribution pattern} of Abdominal Tuberculosis

$10 \%$ of patients had abdominal tuberculosis in our study

\begin{tabular}{|c|c|c|}
\hline TBM & No. of patients & \% \\
\hline Absent & 96 & 96.0 \\
\hline Present & 4 & 4.0 \\
\hline Total & 100 & 100.0 \\
\hline
\end{tabular}

Table 7: Showing distribution pattern of Tubercular Meningitis

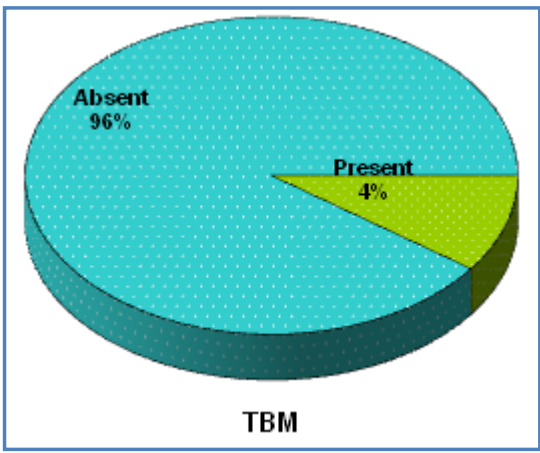

Fig. 6: Showing distribution pattern of Tubercular Meningitis

In our study $4 \%$ of our patients had tubercular meningitis

\begin{tabular}{|c|c|c|}
\hline Haemoglobin & No. of patients & $\mathbf{\%}$ \\
\hline$<6$ & 7 & 7.0 \\
\hline $6.1-7$ & 7 & 7.0 \\
\hline $7.1-8$ & 8 & 8.0 \\
\hline $8.1-9$ & 15 & 15.0 \\
\hline $9.1-10$ & 12 & 12.0 \\
\hline$>10$ & 51 & 51.0 \\
\hline Total & 100 & 100.0 \\
\hline
\end{tabular}

Table 8: Showing distribution pattern of Haemoglobin concentration. 


\section{ORIGINAL ARTICLE}

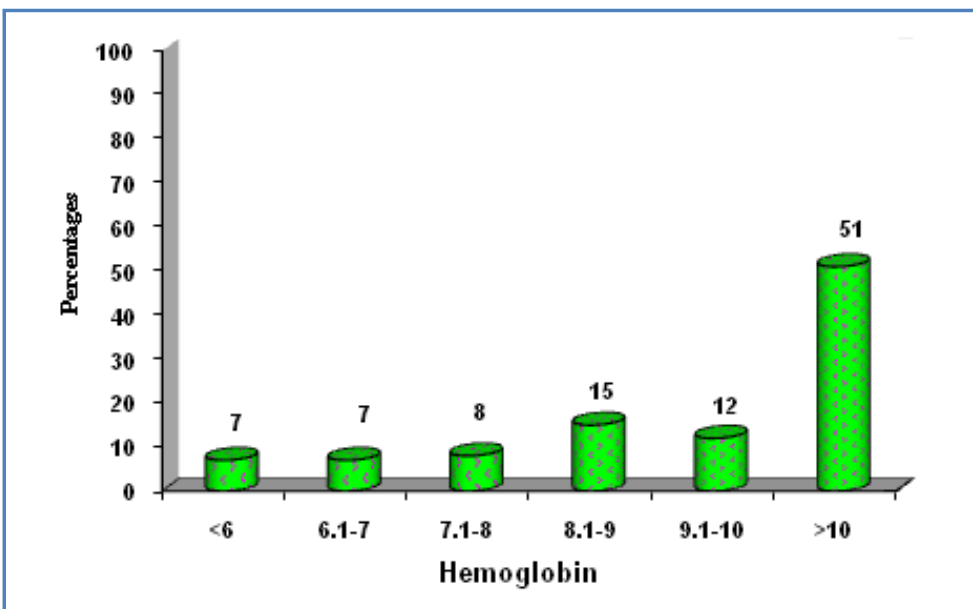

Fig. 7: Showing distribution pattern of Haemoglobin concentration.

In this study $14 \%$ patients had severe anaemia.

\begin{tabular}{|c|c|c|}
\hline ESR & No. of patients & $\mathbf{\%}$ \\
\hline$<30$ & 4 & 4.0 \\
\hline $31-40$ & 5 & 5.0 \\
\hline $41-50$ & 14 & 14.0 \\
\hline $51-60$ & 18 & 18.0 \\
\hline$>60$ & 59 & 59.0 \\
\hline Total & 100 & 100.0 \\
\hline
\end{tabular}

Table 9: Showing distribution pattern of ESR

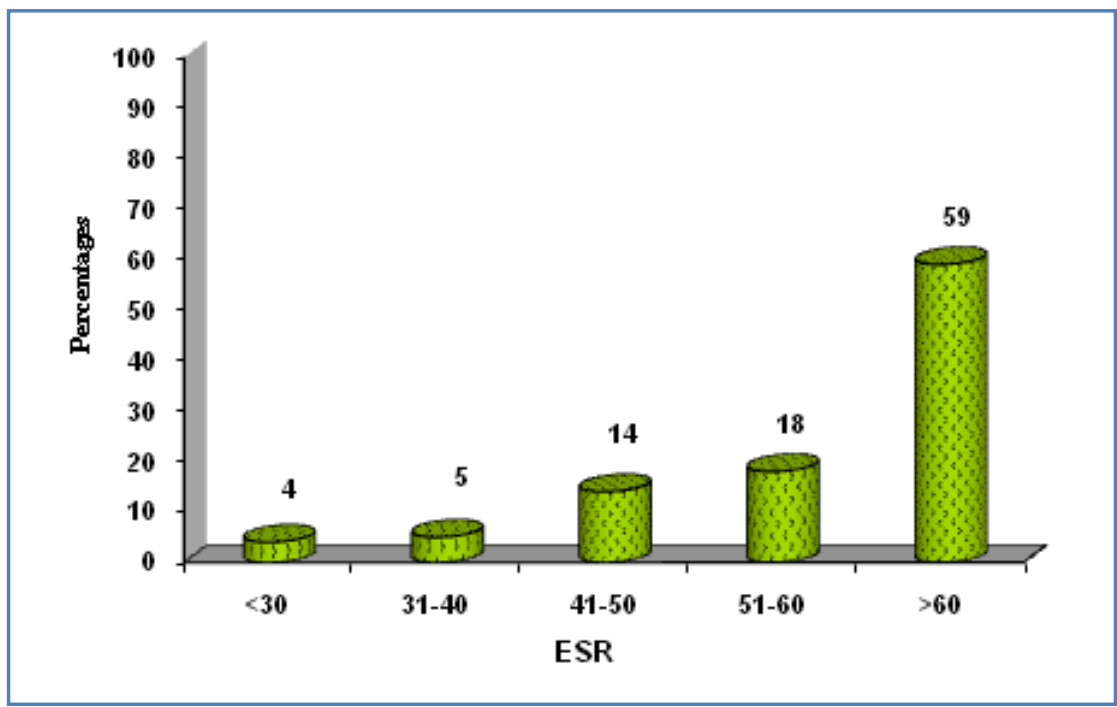

Fig. 8: Showing distribution pattern of ESR

In our study $59 \%$ patients had high ESR $(>60)$ 


\begin{tabular}{|c|c|c|}
\hline Absolute lymphocyte count (ALC) & No. of patients & $\mathbf{\%}$ \\
\hline$<500$ & 18 & 18.0 \\
\hline $501-1000$ & 42 & 42.0 \\
\hline $1001-2000$ & 36 & 36.0 \\
\hline$>2000$ & 4 & 4.0 \\
\hline Total & 100 & 100.0 \\
\hline $\begin{array}{r}\text { Table 10: Showing distribution pattern of } \\
\text { Absolute lymphocyte count (ALC). }\end{array}$ \\
\hline
\end{tabular}

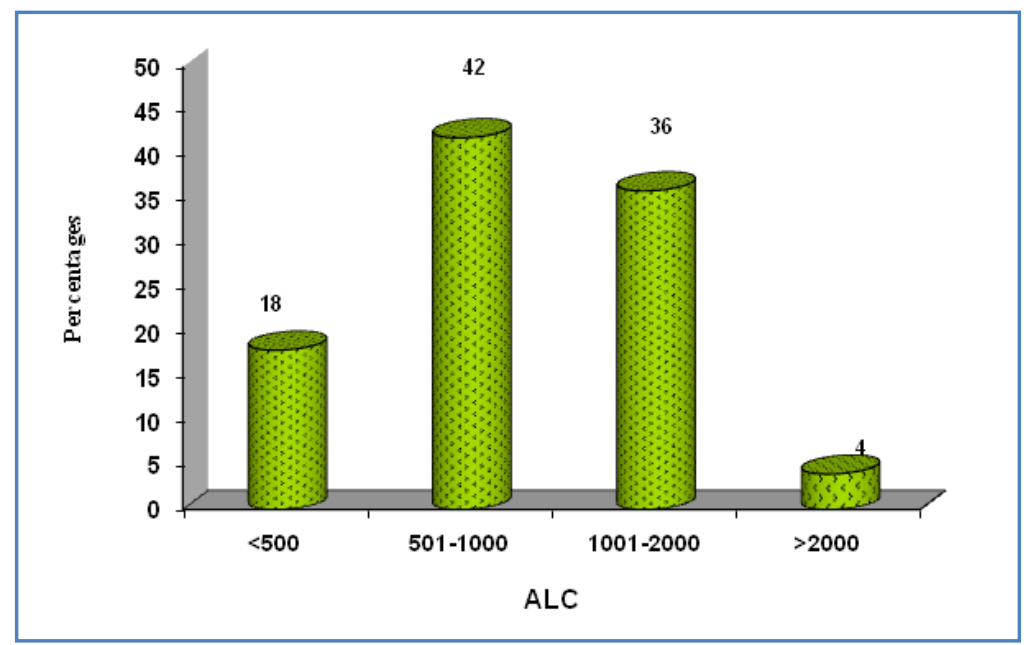

Fig. 9: Showing distribution pattern of ALC

$60 \%$ patients had ALC $<1000 / \mathrm{mm}^{3}$ and $40 \%$ patients had $>1000 / \mathrm{mm}^{3}$ in this study

\begin{tabular}{|c|c|c|}
\hline CD4 count & No. of patients & $\mathbf{\%}$ \\
\hline $1-100$ & 14 & 14.0 \\
\hline $101-200$ & 32 & 32.0 \\
\hline $201-500$ & 35 & 35.0 \\
\hline$>500$ & 19 & 19.0 \\
\hline Total & 100 & 100.0 \\
\hline
\end{tabular}

Table 11: Showing distribution pattern of CD4 count. 


\section{ORIGINAL ARTICLE}

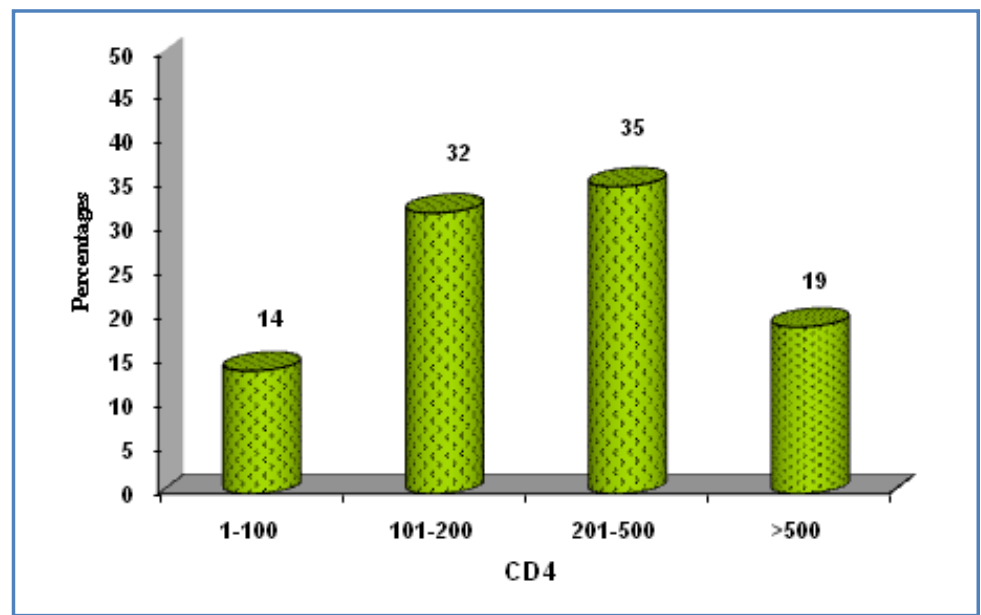

\section{Fig. 10: Showing distribution pattern of CD4 counts.}

In our study $46 \%$ patients had CD4 count of less than $200 / \mathrm{mm}^{3}$ and $54 \%$ patients had $>200 / \mathrm{mm}^{3}$

\section{AUTHORS:}

1. Anil Mudda

2. Satyanarayana $\mathrm{N}$.

3. T. Anil Kumar

4. Sanjeev Kumar S. Gunjigavi

5. Ravi Kumar

6. Sai Shruthi

\section{PARTICULARS OF CONTRIBUTORS:}

1. Post Graduate, Department of General Medicine, ESIMC \& PGIMSR.

2. Professor, Department of General Medicine, ESIMC \& PGIMSR.

3. Professor and HOD, Department of General Medicine, ESIMC \& PGIMSR.

4. Post Graduate, Department of General Medicine, ESIMC \& PGIMSR.
5. Post Graduate, Department of General Medicine, ESIMC \& PGIMSR.

6. Post Graduate, Department of General Medicine, ESIMC \& PGIMSR.

\section{NAME ADDRESS EMAIL ID OF THE} CORRESPONDING AUTHOR:

Dr. Anil Mudda,

Room No. F5, PG Hostel,

ESIC Medical College,

Rajajinagar, Bangalore - 10.

Email-anil_mudda@yahoo.com

Date of Submission: 01/12/2013.

Date of Peer Review: 04/12/2013.

Date of Acceptance: 20/12/2013.

Date of Publishing: 01/01/2014 